\title{
HUBUNGAN PENGGUNAAN KONTRASEPSI HORMONAL DENGAN OBESITAS PADA WANITA USIA SUBUR (WUS) DI PUSKESMAS WAWONASA KECAMATAN SINGKIL MANADO
}

\author{
${ }^{1}$ Mulyana Hasan \\ ${ }^{2}$ Nelly Mayulu \\ ${ }^{2}$ Shirley Kawengian
}

\author{
${ }^{1}$ Kandidat Skripsi Fakultas Kedokteran Universitas Sam Ratulangi \\ ${ }^{2}$ Bagian Ilmu Gizi Fakultas Kedokteran Universitas Sam Ratulangi Manado \\ Email: ana.hasan82@gmail.com
}

\begin{abstract}
Obesity is caused by several factors, one of them is the use of contraception in particular the use of hormonal contraceptives that its use can cause various side effects such as changes in body weight-acceptor. The research aims to determine the relation of hormonal contraceptive use with obesity in women of childbearing age (WUS) of public health insurance participants in the Wawonasa clinic. This study is an Observational Analytics with cross-sectional and conducted in Wawonasa clinic Singkil district Manado with data collection in the form of identity, body weight, height, and direct interviews with the respondents. The total sample of 77 respondents. The respondents who use hormonal contraception are 49 respondents while the respondents who did not use contraception are 28 respondents. The respondents who use hormonal contraception and were obese are 22 respondents. Conclusion: The type of contraception most widely used by women of childbearing age at Puskesmas Wawonasa is hormonal contraceptives and there is no relationship between the use of contraception with obesity in women of childbearing age at Wawonasa clinic.
\end{abstract}

Keywords: hormonal contraceptives, obesity, women of childbearing age

\begin{abstract}
Abstrak: Obesitas disebabkan oleh beberapa faktor, salah satunya penggunaan kontrasepsi khususnya kontrasepsi hormonal yang penggunaannya dapat menimbulkan berbagai efek samping seperti perubahan berat-badan akseptor. Penelitian bertujuan untuk mengetahui hubungan penggunaan kontrasepsi dengan obesitas pada wanita usia subur (WUS) peserta jamkesmas di Puskesmas Wawonasa. Penelitian ini bersifat Observasional Analitik dengan pendekatan cross-sectional dan dilakukan di Puskesmas Wawonasa Kecamatan Singkil Manado dengan pengambilan data berupa identitas, berat badan, tinggi badan, dan wawancara langsung terhadap responden. Jumlah sampel sebanyak 77 responden. Jumlah responden yang menggunakan kontrasepsi hormonal sebanyak 49 responden sedangkan yang tidak menggunakan kontrasepsi berjumlah 28 responden. Jumlah responden yang menggunakan kontrasepsi hormonal dan mengalami obesitas sebanyak 22 responden. Simpulan: Jenis kontrasepsi yang paling banyak digunakan oleh wanita usia subur Puskesmas Wawonasa adalah kontrasepsi hormonal dan tidak terdapat hubungan antara penggunaan kontrasepsi dengan obesitas pada wanita usia subur puskesmas Wawonasa.
\end{abstract}

Kata kunci: kontrasepsi hormonal, obesitas, wanita usia subur

Kejadian obesitas di seluruh dunia mencapai tingkatan yang membahayakan. Menurut database WHO (2008), disebutkan bahwa penderita obesitas laki-laki dan perempuan dengan IM $\$ 30$ di beberapa Negara maju seperti Australia berkisar 
25,1\%, Kanada 24,3\%, Republik Korea 7,3\%, Amerika Serikat 31,8\% sedangkan di beberapa Negara berkembang seperti Bahrain 32,6\%, dan Brazil sebesar 19,5\%. ${ }^{1}$

Menurut laporan nasional RISKESDAS 2010 bahwa Prevalensi nasional gabungan kategori berat badan lebih dan obesitas sebesar $21,7 \%$ dengan prevalensi tertinggi obesitas adalah provinsi Sulawesi Utara (37,1\%) dan terendah adalah 13,0\% di propinsi Nusa Tenggara Timur. Prevalensi obesitas pada laki-laki lebih rendah (16,3\%) dibanding perempuan (26,9\%). ${ }^{2}$

Obesitas disebabkan oleh beberapa faktor, antara lain: genetik, asupan energi, aktivitas fisik, lingkungan, psikis, status sosial ekonomi dan penggunaan kontrasepsi khususnya kontrasepsi hormonal. ${ }^{3,4}$

Menurut BKKBN (2011), wanita usia subur adalah wanita usia 18-49 tahun dengan keadaan organ reproduksi berfungsi dengan baik, baik dengan status belum kawin, kawin maupun janda. Sedangkan menurut Depkes (2009), wanita subur adalah wanita usia 15-49 tahun dengan keadaan organ reproduksi berfungsi dengan baik, baik dengan status belum kawin, kawin maupun janda. Wanita usia subur ini yang menjalankan program KB dengan menggunakan kontrasepsi.

Program KB mempunyai tujuan ganda, yaitu menurunkan tingkat kelahiran dan mewujudkan norma keluarga kecil bahagia dan sejahtera. Namun tidak dapat dipungkiri timbulnya konsekuensi lain dari penggunaan alat kontrasepsi khusunya kontrasepsi hormonal.. Hal ini dapat menimbulkan berbagai efek samping di antaranya adalah perubahan berat-badan akseptor. ${ }^{4}$ Hal ini disebabkan oleh hormon progesteron mempermudah perubahan karbohidrat dan gula menjadi lemak, sehingga lemak di bawah kulit bertambah. ${ }^{5}$

Berdasarkan hal tersebut, maka penulis tertarik untuk meneliti bagaimana hubungan penggunaan kontrasepsi dengan obesitas pada wanita usia subur.

\section{METODE PENELITIAN}

Penelitian ini bersifat Observasional Analitik dengan pendekatan Crosssectional dan dilakukan di Puskesmas Wawonasa Keacamatan Singkil Manado selama bulan November 2012 sampai Januari 2013. Populasinya adalah seluruh wanita usia subur (WUS) peserta Jamkesmas di Puskesmas Wawonasa. Pengambilan sampel berdasarkan metode Purposive Sampling dengan sampel penelitian wanita usia subur wanita yang berusia 18-49 tahun dengan keadaan organ reproduksi yang berfungsi dengan baik, baik statusnya belum menikah, menikah maupun janda yang datang berkunjung selama 1 bulan ke Puskesmas Wawonasa. Jumlah wanita usia subur yang terdaftar sebanyak 325 orang dan jumlah responden yang memenuhi kriteria inklusi sebanyak 77 orang yaitu yang berdomisili di wilayah kerja Puskesmas Wawonasa, berusia 18-49 tahun dan bersedia menjadi sampel. Pada penelitian ini digunakan data primer berupa identitasa responden, berat badan, tinggi badan yang digunakan untuk mengetahui IMT responden dan wawancara langsung pada responden untuk mengetahui apakah responden menggunakan kontrasepsi hormonal yaitu kontrasepsi yang mengandung hormon, baik estrogen atau progesteron maupun kombinasi dari keduanya; seperti kontrasepsi oral (pil), kontrasepsi suntik dan kontrasepsi implant.

\section{HASIL PENELITIAN}

Pada penelitian ini gambaran status gizi responden hanya diambil dua kategori yaitu status gisi yang obes dan tidak obes. Data tersebut dapat dilihat pada tabel dibawah ini:

Tabel 1. Gambaran status gizi responden

\begin{tabular}{lll}
\hline Status Gizi & N & $\mathbf{\%}$ \\
\hline Obes & 32 & 41.6 \\
Tidak Obes & 45 & 58.4 \\
Total & 77 & 100,0 \\
\hline
\end{tabular}


Berdasarkan tabel diatas menunjukkan bahwa jumlah responden dengan status gizi Obes sebanyak 32 orang dengan presentase 41.6\% dan yang Tidak Obes sebanyak 45 orang dengan presentase $58.4 \%$.

Dari hasil penelitian diperoleh gambaran penggunaan kontrasepsi hormonal, dari 77 subjek penelitian terdapat 49 orang (63,6\%) yang menggunakan kontrasepsi dan 28 orang $(36,4 \%)$ tidak menggunakan kontrasepsi.

Tabel 2. Distribusi subjek berdasarkan penggunaan kontrasepsi hormonal

\begin{tabular}{lcc}
\hline Kontrasepsi & $\mathbf{N}$ & $\mathbf{\%}$ \\
\hline Ya & 49 & 63,6 \\
Tidak & 28 & 36,4 \\
\hline Total & 77 & 100 \\
\hline
\end{tabular}

Analisis bivariat pada penelitian ini dilakukan untuk membuktikan hipotesis tentang hubungan penggunaan kontrasepsi dengan obesitas pada wanita usia subur (WUS) dengan menggunakan uji ChiSquare. Pada hasil uji diperlihatkan Tabel silang antara penggunaan kontrasepsi hormonal dan obesitas.

Tabel 3. Hubungan penggunaan kontrasepsi hormonal dengan obesitas pada WUS

\begin{tabular}{llclll}
\hline & \multicolumn{3}{c}{ Status Gizi } & & \\
\cline { 2 - 3 } Penggunaan & Obes & Tidak & & Total & P \\
& Kontrasepsi & Obes & & & \\
& $\mathrm{N}$ & $\mathrm{N}$ & & \\
\hline Ya & 22 & 27 & 49 & \\
Tidak & 10 & 18 & 28 & 0.585 \\
Total & 32 & 45 & 77 & \\
\hline
\end{tabular}

Berdasarkan hasil uji statistik dengan menggunakan Chi-square diperoleh nilai $P=0,585>\alpha=0,05$. Hasil ini menunjukkan bahwa tidak terdapat hubungan antara penggunaan kontrasepsi dengan obesitas pada wanita usia subur (WUS) peserta jamkesmas di Puskesmas Wawonasa.

\section{BAHASAN}

Responden pada penelitian ini adalah Wanita Usia Subur (WUS) yang berusia 19-49 tahun. Jumlah responden pada penelitian ini berjumlah 77 orang. Responden didistribusikan berdasarkan karakteristiknya masing-masing yaitu dari aspek umur, pendidikan, pekerjaan, dan pendapatan.

Berdasarkan hasil penelitian, responden terbanyak adalah pengguna kontrasepsi hormonal yaitu sebanyak 49 responden (63,6\%). Dari penelitian ini didapatkan lebih banyak tidak obes daripada yang obes. Hal ini menunjukkan bahwa tidak terdapat hubungan antara penggunaan kontrasepsi dengan obesitas. Hal ini tidak sesuai dengan teori yang menyatakan bahwa penggunaan kontrasepsi hormonal berpengaruh terhadap peningkatan berat badan. Seperti penelitian yang dilakukan terhadap wanita pasangan usia subur di Tasikmalaya menunjukkan bahwa penggunaan alat kontrasepsi berhubungan dengan peningkatan berat badan. ${ }^{6}$

Penelitian pada akseptor di Tasikmalaya menunjukkan bahwa penggunaan berbagai alat kontrasepsi hormonal berkorelasi dengan peningkatan berat badan. ${ }^{6}$ Penelitian yang dilakukan Sri Ratnawati dkk menunjukkan bahwa penggunaan kontrasepsi implant meningkatkan berat badan akseptor di Surabaya. ${ }^{7}$ Selain itu, penggunaan KB suntik juga berpengaruh terhadap peningkatan berat badan seperti yang ditunjukkan pada penelitian oleh Finta dkk di Kediri. ${ }^{8}$

Hasil penelitian status gizi pada wanita usia subur peserta jamkesmas di puskesmas Wawonasa adalah obes $41,6 \%$ dan tidak obes $58,4 \%$ berarti status gizi terbanyak adalah tidak obes. Hal ini kemungkinan ditunjang aktivitas fisik yang tinggi mengingat responden terbanyak adalah ibu rumah tangga. Selain itu pendidikan responden juga mendukung hal ini.

Pada penelitian wanita usia subur yang menggunakan kontrasepsi pil atau suntikan yang komposisinya mengandung hormonal, baik jangka pendek maupun jangka panjang bertujuan untuk mengontrol kehamilan. penggunaan ini banyak dihubungkan 
dengan efek samping yang tidak diinginkan, seperti menstruasi tidak teratur dan kehilangan densitas tulang. Selain itu, pada konsentrasi kadar insulin, misalnya pada penelitian di Mesir pada 20 perempuan yang menggunakan kontrasepsi suntikan selama 12 bulan memperlihatkan kenaikan serum. Kadar serum glukosa baik pada keadaan puasa maupun pada dua jam setelah makan pada akhirnya efek potensial terjadi obesitas melalui kenaikan kadar insulin dan glukosa. ${ }^{9}$

Pada penelitian ini menunjukkan bahwa tidak ada hubungan antara penggunaan kontrasepsi dengan obesitas $(P>0,05)$. Hal ini mungkin karena dipengaruhi oleh tingkat pendidikan yang cukup tinggi dan pekerjaan dalam hal ini sebagai ibu rumah tangga yang beraktivitas fisik cukup tinggi.

Sedangkan pada penelitian yang dilakukan oleh Lee, et al (2009) memperlihatkan kenaikan berat badan secara signifikan dengan penggunaan kontrasepsi depot medroxy progesterone asetat (DMPA). Kenaikan berat bedan terjadi berkisar 3,0 kg selama 12 bulan hingga 9,4 kg selama 18 bulan. Penelitian tersebut hanya berfokus pada kenaikan berat badan. ${ }^{10}$ Namun pada penelitian ini tidak diperinci jenis kontrasepsi hormonal yang digunakan dengan sampel 77 orang serta pola kenaikan berat badan.

Seperti diketahui bahwa Gonadal steroid hormone (GSH), dalam hal ini androgen, estrogen dan progestin merupakan molekul yang pluripoten signaling dengan aktivitas biologi yang bervariasi yang kebanyakan daripadanya tidak jelas hubungan antara fungsi primer reproduksi dengan hipothalamo-pituitary gonadal axis (HPG-axis). ${ }^{11}$

GSH berpengaruh secara independen terhadap kenaikan berat badan dan makan makanan lemak, termasuk juga terhadap energy expenditor dan fungsi saluran cerna, metabolisme, pertumbuhan dan komposisi tubuh. ${ }^{11}$ Mekanisme yang mendasari hal ini dan hubungannya dengan makan perlu dilakukan penelitian lebih lanjut.
HPG axis mempunyai efek secara hirarki yaitu: (i) hypothalamic releasing hormone GnRH (atau LHRH), yang mensintesis sel-sel neuronal bodies yang terletak pada nucleus arkuata area preoptik, (ii) hormon pituitary anterior, FSH dan LH, (iii) gonadal hormon, testosteron, estrogen dan progesteron yang bekerja pada sejumlah jaringan target. Masing-masing bertindak sebagai control feedback terhadap fungsi HPG melalui reseptor hipthalamus dan pituitary. ${ }^{11}$

\section{SARAN}

Bagi orang obes sebaiknya menurunkan berat badan dengan mengatur pola makan sehat dan aktivitas yang cukup, bagi pengguna kontrasepsi pada pasangan usia subur perlu di adakan penjelasan tentang risiko adanya peningkatan berat badan atau obesitas, serta perlu diadakan penelitian lanjutan tentang masalah dampak kontrasepsi hormonal dan kejadian obesitas.

\section{SIMPULAN}

Proporsi obesitas pada wanita usia subur (WUS) di Puskesmas Wawonasa adalah $41.6 \%$. Jenis kontrasepsi yang digunakan oleh wanita usia subur Puskesmas Wawonasa paling banyak adalah kontrasepsi hormonal. Tidak terdapat hubungan antara penggunaan kontrasepsi dengan obesitas pada wanita usia subur puskesmas Wawonasa.

\section{UCAPAN TERIMA KASIH}

Ditujukan kepada Ibu Anita Basuki, SKM, MKes, dr. Alexander S. Bolang, Mkes, AIFO dan kepada semua pihak yang baik secara langsung ataupun tidak langsung telah menumbuhkan ide atau gagasan pada penulis sehingga penulis dapat menyelesaikan artikel ini.

\section{DAFTAR PUSTAKA}

1. World Health Organization (WHO). Overweight / obesity: obesity (body mass 
index\&ge; 30). 2012 [cited 2012 Okt 30]. Available from:

http://apps.who.int/gho/data/?vid=2450

2. Badan Penelitian dan Pengembangan Kesehatan Kementrian Kesehatan RI. Laporan riset kesehatan dasar 2010. Jakarta:2010

3. Adriani M, Wirjatmadi B. Pengantar gizi masyarakat. Jakarta: Penerbit Kencana; 2012.p.115-19,114-115,125

4. Nirwana, Hasyifah, Magdalena. Pengaruh penggunaan kontrasepsi hormonal terhadap perubahan berat badan akseptor KB di RSIA Pertiwi Makassar. Journal from e-library STIKES Nani Hasanudin. 2012;I.

5. Kundarti FI, Lumastari AW. Hubungan KB suntik depo medroksiprogesteron asetat dengan peningkatan berat badan pada akseptor suntik di Rumah Bersalin Kasih Ibu desa Wonoasri kecamatan Grogol kabupaten Kediri. Tunas-tunas Riset Kesehatan. 2012;2:78

6. Millah, hidayati L. dampak penggunaan berbagai alat kontasepsi terhadap indeks massa tubuh pada wanita pasangan usia subur. Universitas Siliwangi: 2012
7. Ratnawati S, Isfentiani D, Widiasti S. Hubungan penggunaan KB implant dengan peningkatan berat badan pada peserta implant di RB Kartini Surabaya. Jurnal Penelitian Kesehatan Suara Forikes. 2011;2:164-165

8. Setyaningsih, Wineh R, Teresia RP. Dampak kenaikan berat badan pada akseptor KB suntik DMPA terhadap citra tubuh di Polindes Sekar Arum kecamatan Grabagan kabupaten Tuban. Jurnal Keperawatan. 2010;3:85

9. Berenson $A B$, Van den Berg P, Williams KJ, Rahman M. Effect of injectable and oral contraceptives on glucose and insulin level. Obstet Gynecol 2011;117(1):41-47

10. Lee YC, Rahman M, Berenson AB. Earlu weight gain predicting hater weight gain among depot medroxy progesterone acetate users. Obstet Gynecol 2009;114(2 pt 1):279-84

11. Asarian L, Geary N. Modulation of appetite by gonadal steroid hormones. Phil Trans R Soc B 2006;361:1251-63. 